\title{
Theory: the X Factor in Librarianship
}

\begin{abstract}
Librarians have come to recognize the value of research to the profession, and much collecting of data is being accomplished. Most of the library literature, however, results from mission-oriented investigation. This is perhaps to be expected since much library research is conducted by practicing librarians who set out to solve their own problems and then report the results in print. There has been little attempt thus far to develop an adequate theoretical framework into which practical research can be hung. Such an examination of the theoretical bases of librarianship will probably have to be made by library educators rather than by practitioners.
\end{abstract}

L and at times in history has been the respected occupation of prominent scholars. Today, however, teachers of librarianship and practicing librarians are often frustrated and exasperated by the low status assigned to their branch of knowledge by the intellectual world. Philip H. Ennis of the University of Chicago has stated that “. . . the history of librarianship... [ [has been] a long spiral of downward mobility." 1

Librarians frequently are sensitive and uncertain about their place in the academic spectrum. They offer various solutions to the problem, one of these being an emphasis on research. The idea of increased research has been readily accepted by many, and yet even with special

\footnotetext{
${ }^{1}$ Philip H. Ennis and Howard W. Winger (eds.), Seven Questions About the Profession of Librarianship, Twenty-Sixth Annual Conference of the Graduate Library School, June 21-23, 1961 (Chicago: University of Chicago Press, 1962), p.3.
}

Mrs. Petrof is Assistant to the Dean of the School of Library Service, Atlanta University. emphasis on research, librarianship will have a difficult time finding its proper academic niche as long as the research is not organized within a theoretical framework. Scholars in many fields younger than librarianship have realized the importance of conducting investigations and experiments with a frame of reference in mind. If librarianship is to receive its due recognition it must move to higher levels of abstraction; it must have a theory.

Some readers may disagree completely with this thesis; there are some teachers of librarianship and practitioners who believe that the subject matter of the profession cannot afford theoretical treatment or that such treatment is not necessary. These viewpoints are supported by the fact that at present there is no generally accepted library theory. Of course, this point of view is not new; as a matter of fact, were there a workable theory there would be no need for this paper. The failure of librarians to develop an adequate theory is no indication that one cannot be developed, anymore than the 
failure of physicists to develop an atomic bomb prior to World War II meant that it would be impossible to do so.

Librarianship needs a theory to provide clarity of conception and to enable librarians to venture into the realm of supposition. This is the belief of many responsible librarians and is further evidenced by the acceleration of research in librarianship, which in part is a result of the increased participation of philanthropic organizations, businesses, universities, governments at all levels, and various other sources, such as the Council on Library Resources. Unfortunately, these efforts have been directed primarily toward solving the problems of particular library systems or toward simple information-gathering about current library practices. All librarians are familiar with the how-my-library-did-it type of article which is prevalent in library literature. In addition, many library spokesmen have voiced resentment and concern about the abusive use of research methods, producing results which have no scholastic value. ${ }^{2}$

Some are distressed by the lack of interest in the profession concerning the development of a theory. A professional publication can nearly always be considered a reflection of its readers' attitudes. In writings in librarianship one frequently finds a proliferation of descriptive summaries without an attempt being made to appraise their analytical importance relative to the problem or problems involved. Many times relationships and cross-relationships are completely ignored. Few people would question the value of empiricism in developing a realistic library theory, but facts without theories may be meaningless. It is very difficult to analyze and evaluate empirical facts without a proper frame of reference.

Library literature has put too much

\footnotetext{
2 The July 1964 issue of Library Trends is devoted to research methods. Several of the articles offer useful eriticisms.
}

emphasis upon research descriptions and findings at the expense of analysis. As long as research is application-oriented, it is difficult to nurture much hope for a comprehensive theory. The future of a theory depends on efforts at the intellectual, individualistic level. This would require a shift in emphasis from factfinding and application to integration of existing knowledge.

Academicians in librarianship, it would seem, must bear the moral responsibility for fulfilling this very important task. Most practitioners' efforts are centered around problem-solving rather than the discovery of new regularities and their elucidation. Environmental pressures and limitations make such action condonable in the case of practitioners, but the same cannot be said for library science teachers. Mrs. Joan Robinson, respected British economist, once complained that in economics the gap between the tool-maker and the tool-user is a distressingly large one. ${ }^{3}$ Librarianship seems to be at the opposite extreme of such a trying situation. Tool-makers are so few in librarianship that their number is inadequate, relatively speaking, to create a gap.

Gaps and dichotomies within a profession may be considered undesirable under most conditions, but a polarity of theoreticians and practitioners might prove useful for the sake of the expeditious development of a library theory. It behooves teachers of librarianship to assume the leadership in making workable and reliable tools available to library practitioners. Practitioners in turn should generously support academic efforts in developing a library theory. Such efforts may not produce immediate tangible benefits, but the results will be rewarding in the long run. A reliable theory, the whole, will undoubtedly prove to be more useful than a mere collection of descriptive data.

\footnotetext{
3 Joan Robinson, The Economics of Imperfect Competition (London: Macmillan and Company, 1948), p.1.
} 